\title{
SENSE OF BELONGING AND SOCIAL CLIMATE IN AN OFFICIAL LANGUAGE MINORITY POST-SECONDARY SETTING
}

\author{
KAILEY PENNER \\ UNIVERSITÉ DE SAINT-BONIFACE \\ FLORETTE GIASSON \\ UNIVERSITÉ DE SAINT-BONIFACE
}

DANIELLE DE MOISSAC
UNIVERSITÉ DE SAINT-BONFFACE

KEVIN PRADA
UNIVERSITÉ DE SAINT-BONFFACE
RHÉA ROCQUEE
UNIVERSITÉ DE SAINT-BONIFACE

PAUL BROCHU

UNIVERSITÉ DE SAINT-BONFFACE

\begin{abstract}
Perceived sense of belonging and positive social climate on campus are crucial elements for post-secondary students, as they contribute to academic achievement, positive mental health, and help-seeking. Few studies have explored post-secondary students' sense of belonging and perceptions of social climate in an official language minority campus, which attract Canadian-born francophones, anglophones who pursue higher education in their second language, and francophone international students. With declining student mental health and greater ethnolinguistic diversity of post-secondary students on Canadian campuses, this important study aims to explore francophone students' perceived sense of belonging and social climate on campus. In total, 35 students from different ethnolinguistic backgrounds took part in focus groups or individual interviews. Domestic students with French as their first language more often reported positive social climate on campus and a sense of belonging, in contrast to international students and students with French as a second language. A common obstacle to connecting with others was language insecurity in one of the official languages, as both are currently used on campus. Universities hosting students of multiple linguistic diversities should provide courses and campus events to stimulate intercultural knowledge and dialogue.
\end{abstract}

Keywords: post-secondary, sense of belonging, social climate, official language linguistic minority, language insecurity

\section{Résumé}

Pour les étudiants de niveau postsecondaire, une perception positive du climat social et un sentiment d'appartenance sont essentiels, car ils contribuent à la réussite scolaire, à une bonne santé mentale et à la recherche d'aide. Peu d'études ont exploré le sentiment d'appartenance et les perceptions du climat social chez les personnes qui étudient dans un établissement postsecondaire en situation de minorité linguistique attirant des francophones d'origine canadienne, des anglophones qui poursuivent des études supérieures dans leur langue seconde et des étudiants internationaux francophones. En raison du déclin de la santé mentale des étudiants et d'une plus grande diversité ethnolinguistique sur les campus canadiens, cette étude importante vise à explorer le sentiment d'appartenance et le climat social perçus par les étudiants francophones sur le campus. Au total, 35 étudiants d'origines ethnolinguistiques variées ont participé à des groupes de discussion ou des entretiens individuels. Les étudiants canadiens dont le français est la langue maternelle ont plus souvent signalé un climat social positif sur le campus et un sentiment d'appartenance que les étudiants internationaux et les étudiants dont le français est la langue seconde. L'insécurité linguistique dans l'une des langues officielles, toutes deux étant couramment utilisées sur le campus, était un obstacle considérable aux échanges entre étudiants. Les universités accueillant des étudiants de profils ethnolinguistiques variés devraient donc proposer des cours et des événements sur le campus pour stimuler la connaissance et le dialogue interculturels.

Mots-clés : postsecondaire, sentiment d'appartenance, climat social, minorité de langue officielle, insécurité linguistique 


\section{Introduction}

Post-secondary institutions are ideal settings for emerging adults to meet others and develop new friendships. At this time in their life, when personal and psychosocial identities continue to develop (Arnett, 2000), emerging adults benefit from interacting with their peers and being exposed to different cultures and new ideas. Ideally, this learning environment should provide opportunities for students to engage with others, whether in the classroom, team sports, or clubs, thus contributing to the campus ambiance. Social climate, or the perception of a social environment shared by a group of people (Bennett, 2010), is shaped by relationships among students and between students and professors (Allodi, 2010). As students engage with others, they learn about themselves and others, and develop a sense of belonging, or feelings of connectedness and being a valued member of the community (Hausmann et al., 2007). A welcoming social environment plays an important role in the development of sense of belonging for post-secondary students (Wells \& Horn, 2015) which, in turn, is predictive of academic persistence and achievement (Franco \& Kim, 2018; Gopalan \& Brady, 2019; Meeuwisse et al., 2010), positive mental health (Backhaus et al., 2021; Gummadam et al., 2016; McGuirk \& Frazer, 2021), and the likelihood of students seeking mental health services (Stein et al., 2016). As such, efforts should be made to enhance the social climate and promote the sense of belonging in higher education.

In a linguistic minority setting, social climate may prove to be of greater importance; social interactions with members within the ethnolinguistic group and with majority outgroups play a significant role in ethnolinguistic identity development (Pilote \& Joncas, 2016). A strong attachment to one's ethnolinguistic collective identity is generally associated with a sense of belonging to this group (Berry, 2005; Tajfel, 1978; Taylor, 1997). Qualitative studies conducted in four Canadian provinces where official language minority groups live demonstrate varying collective identity profiles among young adults (Benoit et al., 2018). In these studies, one's ability to personally and collectively identify with such a group has been shown to benefit psychological well-being (Bahi \& Mulatris, 2018; Levesque \& de Moissac, 2018), as has been previously reported for other Francophone minority groups in Canada (DeCou et al., 2013; Levesque, 2015; Noël \& Beaton, 2010). Providing opportunities to explore one's cultural and linguistic history and experience its heritage appears to be beneficial for ethnolinguistic minority post-secondary students.

What has yet to be explored is the sense of belonging of emerging adults to a post-secondary institution in an official language minority setting, where the teaching language is that of the language of the minority. As these institutions attract students from different linguistic and ethnic backgrounds, including Canadian-born francophones, anglophones who pursue higher education in their second language, and francophone international students, how is the sense of belonging and campus climate perceived, and what is their impact on student well-being? A recent quantitative study on student mental health and risk-behaviour in such a setting revealed declining mental health status among students (Rocque et al., 2019) and higher prevalence of depression as compared to students in an English language post-secondary institution in the same province (de Moissac et al., 2019). While exploring factors influencing mental health of students on this campus, the role of belonging and campus climate was suggested. This led the research team to conduct this current qualitative study to better understand what factors influence post-secondary students' well-being, particularly within a linguistic minority context. More specifically, students' sense of belonging to their post-secondary institution, as well as their description of the campus social climate, were explored.

\section{Ethnolinguistic Minorities}

Canada, a bilingual country, has two official languages: English and French. Although francophones represent the majority in the province of Quebec (85\%), they represent only $3.8 \%$ of the population in other provinces and territories, according to the 2016 census (Canadian Heritage, n.d.). Thus, outside of Quebec, francophones belong to official language minority communities (OLMC). Studies have shown that members of OLMC have been subjected to minoritisation (Lafrance, 2008), defined as "the different ways in which unequal power relations between minority and majority groups are manifested in systems and structures that perpetuate privilege" (Pratt et al., 2004, p. 33). The process of minoritisation has an impact on identity development (Lafrance, 2008) and mental health: Francophones in a minority setting in Canada are more likely to report their mental health negatively (Bouchard et al., 2018; Chartier et al., 2014), and to present higher lifetime prevalence of depressive 
episodes when compared to anglophones (Puchala et al., 2013). As mentioned previously, students who attend a French-language post-secondary establishment were more likely to report depressive symptomology as compared to students studying at an English-language post-secondary establishment in the same province (de Moissac et al., 2019). Gaining a better understanding of factors which might impact well-being of official language minority (OLM) groups is warranted.

\section{Post-Secondary Institutions in Official Language Minority Communities}

Canadian post-secondary francophone establishments are unique, as they host students with diverse linguistic profiles. Not only do these establishments welcome Canadian-born francophones; they also accommodate students whose native language is English. Many of these students are pursuing post-secondary education in French because bilingualism is considered a valuable asset in many careers (Givergis, 2019). Little research pertains to how these French-immersion students fare in higher education: literature reports mostly on student academic engagement, and sociolinguistic performance and competence (Mougeon \& Rehner, 2015; Yang \& Rehner, 2015). In a study by Gueye et al. (2018), anglophones studying in their second language showed lower mental health scores when compared to francophone and international students. The researchers of this previous study posit that this could be due to low ethnolinguistic identity among anglophone students (Gueye et al., 2018), but further research on this topic has yet to be explored.

International students are increasingly present on Canadian post-secondary campuses. During their transition into Canadian society (Smith et al., 2013), these students may experience loneliness, isolation (Mesidor \& Sly, 2016), and discrimination (Shadowen et al., 2019). Some studies suggest these students are at greater risk of experiencing psychological distress than their domestic counterparts (Clough et al., 2018; Shadowen et al., 2019 ) in response to the acculturation process (Huang \& Mussap, 2018). This process, a period of dynamic cultural and psychological change resulting from contact between members of two or more cultural groups (Berry, 2005), may impact beliefs, values, identity, and behaviour (Thomson \& Hoffman-Goetz, 2009). Shadowen and colleagues (2019) suggest that language barriers may in- tensify acculturative stress; barriers in communication may impede participation in class lectures, assignment quality, and creation of positive social connections with domestic students, as well as hinder help-seeking. Of interest, international students in our 2018 study were more likely to report flourishing mental health but less likely to talk about their hardships than domestic respondents (de Moissac et al., 2020). Although other studies have gathered information on the mental health of international students attending post-secondary education (Clough et al., 2018; Huang \& Mussap, 2018; Shadowen et al., 2019), few have investigated the perception of belongingness and campus climate for students of diverse linguistic backgrounds in a minority setting.

\section{Purpose of Research}

Considering the linguistic diversity of post-secondary students on Canadian campuses in OLMC, and the declining mental health of these students (Rocque et al., 2019), this study was conducted to explore factors which may contribute to languishing mental health for minority groups, including those of the OLM, international students, and students studying in a second language. As suggested by other studies, a positive social climate and sense of belonging may have an impact on the mental health of post-secondary students. Our research questions were: What are students' perceptions of the climate and ambiance on campus? What are students' perceptions of the sense of belonging on campus? Our goal was to understand post-secondary students' perspectives regarding campus social climate, and sense of belonging in an OLMC. To our knowledge, this is the first in-depth exploration of these topics with minority subgroups within a Canadian linguistic minority post-secondary institution.

\section{Methods}

\section{Study Design, Context, Participants, and Recruitment}

The present study used a qualitative approach, gathering information through focus groups and individual semi-structured interviews to complement previous quantitative findings by the research team on the well-being of students studying in a linguistic minority context 
(de Moissac et al., 2019; Rocque et al., 2019). The previous quantitative study involved 664 post-secondary students, consisting largely of female students (about $70 \%$ ), and students who were on average 22 years old. The study was conducted in an urban French-language post-secondary institution located in the majority anglophone province of Manitoba. The findings of this previous study were compared to the findings of four other similarly sized universities, including one in the same province, where the teaching language was the majority language of the province (English). As findings suggested that students studying on a francophone campus reported higher depressive symptomology than students studying in English, (de Moissac et al., 2019), the research team wanted to further investigate why this was the case.

Inclusion criteria to participate were being between the ages of 18 and 24 and enrolled at Universite de Saint-Boniface, a French-language university in Winnipeg, Manitoba. Efforts were undertaken to have equal representation based on gender (male and female) and ethnolinguistic group (francophones, anglophones with French as a second language, and international students). Students self-identifying as belonging to a sexual or gender minority were also recruited. Among interview questions, two pertained to the focus of this article: What are students' perceptions of the climate and ambiance on campus? What are students' perception of the sense of belonging on campus?

After receiving approval from the Research Ethics Committee at Université de Saint-Boniface, an email detailing the purpose and the procedure of the study was sent to all students by the institution's Student Association and International Office; research assistants also publicized the study in classrooms where student numbers were high. Students were invited to complete an online sociodemographic survey to ensure eligibility. In total, six focus groups were conducted; efforts were undertaken to have eight to 10 participants in each group. However, the number of participants ranged from two to nine, due to occasionally low turnout. Participants who expressed interest in participating, but were unable to attend scheduled focus groups, were invited to participate in an individual interview. Seven individual interviews were conducted.

\section{Participant Demographics}

Participant demographics are presented in Table 1. In total, 35 students took part in this study, of which 15 self-identified as francophones, 14 as international students, and six as anglophones with French as a second language. The average age of participants was 19.83 years. Slightly more than half of the participants identified as female ( $n=18 ; 51 \%)$, and the majority identified as heterosexual. Anglophone students with French as a second language were underrepresented as compared to the two other groups, especially among male students. The country of origin of most participants was Canada or a French-speaking African country. A greater proportion of participants were in their first year of study.

\section{Procedure}

Interviews were conducted from January to March 2020, prior to the COVID-19 pandemic outbreak in our province. Focus groups and individual interviews took place in a private room on campus. Participants provided written consent and received monetary compensation (\$20) prior to participation. Focus groups were facilitated by a research team member, and individual interviews were conducted by either a researcher or a trained research assistant. Interview questions focused on students' perception of social climate and sense of belonging on campus. Interviews were audio-recorded and transcribed verbatim by a research assistant. Names of participants were coded with pseudonyms, as presented in Table 2; participant ethnolinguistic and sexual identity are also presented.

\section{Analysis}

Qualitative thematic analyses were performed using NVivo 12 (QSR International). Passages were initially sorted into four main categories: (a) sense of belonging, (b) social climate, (c) barriers to belonging and positive social climate, and (d) facilitators to belonging and positive social climate. An inductive approach was then used to code sub-themes within each category. Initially, two researchers and the trained research assistant coded three focus group transcripts independently. Codes were then discussed; when disagreements occurred, a consensus was obtained by discussion with the research team. The remaining transcripts were then coded by the trained research assistant. Findings were summarized and discussed by the research team for interpretation. Investigator triangulation (Archibald, 2016) was used: members of the research team were from different disciplines (psychology, social work, health studies, 


\section{Table 1}

Participant Demographics

\begin{tabular}{|c|c|}
\hline Characteristic & $n(\%)$ \\
\hline \multicolumn{2}{|l|}{ Gender } \\
\hline Female & $18(51.4)$ \\
\hline Male & $15(42.9)$ \\
\hline Non-binary & $2(5.7)$ \\
\hline \multicolumn{2}{|l|}{ Sexual orientation } \\
\hline Heterosexual & $25(75.8)$ \\
\hline Bisexual & $5(15.2)$ \\
\hline Other (homosexual, queer, questioning) & $3(9.1)$ \\
\hline \multicolumn{2}{|l|}{ Ethnolinguistic identity } \\
\hline Francophone from abroad & $15(42.9)$ \\
\hline Franco-Manitoban & $14(40.0)$ \\
\hline Anglophone with French as second language & $6(17.1)$ \\
\hline \multicolumn{2}{|l|}{ Country of origin } \\
\hline Canada & $17(49.0)$ \\
\hline Morocco & $6(17.0)$ \\
\hline Democratic Republic of Congo & $4(11.0)$ \\
\hline Other (France, Philippines, other African countries) & $8(23.0)$ \\
\hline \multicolumn{2}{|l|}{ Academic year } \\
\hline 1st year & $21(60.0)$ \\
\hline $2 n d-4$ th year & $14(40.0)$ \\
\hline \multicolumn{2}{|l|}{ Study program } \\
\hline University 1 & $10(29.0)$ \\
\hline Business & $8(23.0)$ \\
\hline Arts & $7(20.0)$ \\
\hline Nursing & $5(14.0)$ \\
\hline Other (Social work, Sciences, Technical college) & $5(14.0)$ \\
\hline
\end{tabular}

Note. $N=35$. Participants were on average 19.83 years old, with a range from 18 to 24 years. 
Table 2

Participant Pseudonyms

\begin{tabular}{|c|c|c|c|}
\hline Gender & Ethnolinguistic identity & Sexual orientation & Pseudonyms \\
\hline Female & Francophone & LGBTQ+ & Céline, Théa, Roxanne \\
\hline Female & Francophone & Heterosexual & $\begin{array}{l}\text { Marie, Béatrice, Dianne, } \\
\text { Jacqueline }\end{array}$ \\
\hline Female & $\begin{array}{l}\text { Anglophone with French } \\
\text { as second language }\end{array}$ & Heterosexual & Taylor, Lily, Kaeley \\
\hline Female & $\begin{array}{l}\text { Anglophone with French } \\
\text { as second language }\end{array}$ & LGBTQ+ & Julia \\
\hline Female & $\begin{array}{l}\text { Francophone with interna- } \\
\text { tional student }\end{array}$ & Heterosexual & $\begin{array}{l}\text { Désiree, Bintou, Fatima, } \\
\text { Awa, Fatoumana, } \\
\text { Mariama, Ines }\end{array}$ \\
\hline Male & Francophone & LGBTQ+ & Antoine, Olivier \\
\hline Male & Francophone & Heterosexual & Cristophe, Timothée, Joel \\
\hline Male & $\begin{array}{l}\text { Anglophone with French } \\
\text { as second language }\end{array}$ & Heterosexual & Wendell, Jim \\
\hline Male & International student & Heterosexual & $\begin{array}{l}\text { Oumar, Cheik, Babacar, } \\
\text { Moustapha, Ibrahim, } \\
\text { Mohamed, Malinka, Sory }\end{array}$ \\
\hline Non-binary & Francophone & LGBTQ+ & Jules, Adrienne \\
\hline
\end{tabular}

Note. $N=35$. LGBTQ = Lesbian, gay, bisexual, transgender, queer, and others.

and sociology) and representative of the three ethnolinguistic groups invited to participate (Canadian-born francophone, francophone from an African country, and anglophone with French as a second language). Thus, intersecting perspectives enriched interpretation of data. Of note, excerpts presented in this article are a free translation, as the interviews were conducted in French.

\section{Results}

\section{Perceptions of Social Climate and Sense of Belonging on Campus}

Participants were invited to describe their perceptions of the social climate on campus, as well as their perceptions of sense of belonging at the university. Two principal themes emerged: participants either viewed the social climate on campus positively and as such, felt a strong sense of belonging, or inversely, perceived the campus social climate negatively with ensuing lack of connection. Additionally, when describing the ambiance, those who described it negatively often provided examples of barriers, whereas participants who responded positively were more likely to identify facilitators; these are presented below.

\section{Positive Perception of Social Climate and Sense of Belonging}

Participants who defined the social climate positively often used words such as "friendly," "accepting," "warm," and "welcoming" to describe the campus ambiance. As such, these students revealed that they either felt a 
strong connection to the university or felt accepted at the university. As Antoine described, "For me, it's much easier to find myself here." The reasons participants revealed feeling a positive social climate and a strong sense of belonging were further discussed, as presented in the following sub-themes: a generally welcoming attitude from students and faculty, a peer support network, French-language education and services, a sense of community, and extracurricular activities.

A common facilitator that emerged that seemed to contribute to the sense of belonging and positive social climate was having friendly and welcoming staff and students. Students were described as "open," "accepting," and "respecting." Participants from rural regions described their experiences on campus as more accepting as compared to their high school experiences. For example, Roxanne, who identified as lesbian, gay, bisexual, transgender, or queer (LGBTQ), mentioned, "Once I got here... I felt more accepted, and I was able to make these connections with my colleagues, and my peers that I just couldn't do at my high school." Professors and teachers were "understanding," compassionate, easy to talk to, and were even described "as more open than students." Sharing the same beliefs and motivations as other colleagues and students in the faculty was described as making a significant difference.

Being on a French-language campus, activities and services are conducted in French. This was greatly appreciated by francophone students, as well as students who genuinely sought to improve their French-language competencies. Additionally, as the campus is smaller in size, with approximately 1,400 students, participants described feeling more connected to others, as they would in their high school environment. Certain personality traits, such as being sociable, having a social network of friends, participating in extracurricular activities, as well as enjoying the multiculturalism on campus, further aided students' integration into the university experience.

\section{Negative Perception of Social Climate and Sense of Belonging}

Nonetheless, the ambiance was also described negatively by some participants. This was more often the case for international students, who described Canadians as unfriendly and closed off toward others. As explained by Oumar: "The climate at the university is like, the climate of Winnipeg: COLD." As such, some international students did not have a strong sense of belonging or connection to the university, which was compounded by limited local support networks, such as family or friends. As expected, some international participants felt a cultural shock when they arrived in Canada. For example, "There were things that at home...you shouldn't do it, it's disrespectful, but here it is normal," as described by Babacar in reference to eye contact with people of authority. Participants with English as their native language also felt the ambiance was uncomfortable, as these students felt uneasy in the environment due to linguistic differences with their peers. With French as the teaching language, students are expected to speak French in class; however, conversations held outside of class are most often in English, confirmed some participants. For anglophone students for whom French is a second language, feeling insecure about the spoken language in the classroom was common; this was qualified by students mentioning having felt "embarrassed" and "inferior" to francophones concerning their quality of spoken French. As Taylor described, "My first language is English, and so I feel it's a bit weird because everyone speaks French here, and I am just not comfortable." For these students, professors were sometimes described as drivers of language insecurity, often reprimanding them for their accents and linguistic errors. Interestingly, language insecurity was also present for international students, for whom some had limited proficiency in English. Several international students acknowledged that what prevented them from getting to know Canadian students was that the latter spoke English during their free time, despite being on a French-language campus. As Fatima said:

I always hear people speaking in English, and I don't speak English very well... and even if you want to make friends, there are those group of friends that speak a lot in English, so that restrains you a bit.

Thus, in addition to the culture shock and the cold climate within the campus walls, language becomes a significant barrier for international students. Not only did these language barriers affect students' sense of belonging and feelings of the social climate, they also impacted their well-being. Anglophone students described being afraid to speak in French or have meetings with their professors because they felt inferior.

Other barriers mentioned by participants were that 
academic requirements and the timing of events prevented them from enjoying the university's social activities, which normally contribute to a positive climate and stimulate a sense of belonging by creating cohesiveness between students. Finally, although professors and faculty were generally described as contributing positively to the social climate and sense of belonging, they were also described as ignorant of the extracurricular demands on students and of their mental health. Professors who did not notice students' anxiety level, or who lowered student self-esteem, were also described as having a negative impact on campus climate and sense of belonging.

\section{Discussion}

This qualitative study set out to explore and describe students' perceived sense of belonging and social climate on a campus in an official language minority community. Facilitators and barriers to creating connectedness and a positive ambiance were identified by students of different ethnolinguistic backgrounds: Canadian-born francophones, anglophones learning in a second language, and international students. Findings suggest that domestic francophone students are more likely to view the campus climate positively and have a strong sense of belonging than their peers, as they are more familiar with the local environment and have prior connections to some students with whom they have attended school. It should be noted that usually, these students have strong linguistic competencies in both official languages and are therefore able to converse in either language with comfort. In contrast, international and anglophone students learning in a second language more often perceived a significant language barrier to developing connections with other students on campus, and thus often felt the campus climate was unwelcoming.

Canadian-born francophone students often described a sense of belonging to the campus, which was sometimes compared to their high school. In francophone schools in OLMC in Manitoba, ethnolinguistic identity is strongly enforced by cultural activities reflecting the values grounded in the history and the battles fought to preserve the French language in a minority province (Cormier, 2020; Robert, 2018). Having been exposed to this cultural influence since a young age, it is not surprising that local francophone post-secondary students in OLMC place greater importance on their ethnolinguistic identity than other students (Cormier, 2020;
Gueye et al., 2018). Interestingly, international students also have a stronger sense of belonging to their own ethnic group as compared to anglophone students; this has been associated to higher mental health scores and may therefore be protective of student well-being (Gueye et al., 2018; Gummadam et al., 2016). Efforts should be made in post-secondary institutions, especially those in OLMC, to promote the cultural heritage of minority populations and celebrate the cultural diversity of its students on campus. Whether through campus events or in targeted courses, an increased understanding and knowledge of ethnic and minority populations (Gummadam et al., 2016; Labrèche \& Piquemal, 2011; Sims et al., 2021) could benefit students, as they learn not only about themselves, but about others. With reflection, exchange of ideas, and connections with others through the cultural identity lens, a sense of belonging could develop, as has been the experience of Métis students in this institution (Gagnon, 2010). With contemporary issues such as reconciliation increasingly present in public discourse, intercultural knowledge and competencies are essential (Deschênes, 2018), and as such, post-secondary institutions play an important role in educating and facilitating dialogue.

The fact that anglophone students studying in their second language, who are more comfortable speaking in English, and international students, who generally have limited proficiency in English but are very fluent in French, both felt disconnected from the university setting and lacked a sense of belonging is somewhat surprising if language is the principal medium by which students engage with one another and build social networks. One would expect that students with less proficiency in French feel less connected in this particular context. However, such is not the case for international students. As highlighted by some participants, despite being in a francophone post-secondary institution, students will more often speak in English outside the classroom; this deters international students from partaking in informal conversations between classes. It has been shown for other minority groups that this language barrier may be a primary stressor in the acculturation process (Chen \& Zhou, 2019) and prevent international students from feeling accepted and valued. However, the use of English in hallways should facilitate inclusion of anglophone students; that is not apparent either. These students feel intimidated linguistically in class and appear to transfer their linguistic insecurity to outside the 
classroom, as reported elsewhere by students in French immersion schools (Cormier, 2020; Pilote \& Magnan, 2008). Ironically, such a campus could provide the space and opportunity for students from diverse linguistic backgrounds and competencies in both official languages to improve upon their language skills. Although not unique to Manitoba, this issue may be more specific to post-secondary institutions in OLMC, where the teaching language is that of the official language of the minority, but where most extracurricular activities and services off campus are in the majority language. In such a context, knowledge of both official languages is necessary. Post-secondary institutions in OLMC could benefit from this unique opportunity and use bilingualism as a recruitment and retention marketing strategy if they are able to support interventions that facilitate interaction between students outside the classroom. This would also benefit OLM communities who strive to improve equity in access to services in the minority language (Drolet et al., 2015; Falconer \& Quesnel-Vallée, 2014), as the upcoming workforce would be more fluent and confident speaking in either official language.

Reported strategies that promote connection between students from diverse origins generally pertain to international students (Martinez \& Munsch, 2019; Thomson \& Esses, 2016). Mentorship programs pairing domestic and international students have some benefit, as the presence of other students and relationships that develop over time with peers are most influential in strengthening their sense of belonging on campus (Franco \& Kim, 2018; Meeuwisse et al., 2010). Other facilitators identified by participants included professors and their role in promoting interaction and connections between students in class. When faculty take interest in the development of their students, recognize their achievements and/or potential to succeed, and encourage them to be involved in on-campus activities, students are more likely to develop a sense of belonging to the campus (Hurtado et al., 2015). In our study, this was especially evident for international students, who at times felt a greater connection with professors than with students. Raising awareness among faculty of the important role professors play in engaging students to interact, thereby facilitating their integration in campus life, could be helpful. With the shift to online learning during the COVID-19 pandemic, professors were ill-equipped to transform face-to-face classroom dialogue into meaningful connectivity with and between students. However, interpersonal relationships may still be achieved through discussion posts, especially if different media (written text, audio, video; Sousa, 2021) and in-class opportunities to share personal experiences (Mehta \& Aguilera, 2020) are provided. Future studies measuring the impact of online learning on student belongingness, campus climate, and well-being should be conducted as students return to in-person learning.

An avenue for future study would be addressing the unique issues faced by LGBTQ post-secondary students in a linguistic minority context. Considering this study included one focus group constituted of LGBTQ students, findings provide unique insight into the dual gender or sexual/linguistic minority students' perspective. Literature has shown the need for targeted supports for LGBTQ students generally (Hunt et al., 2021), as they manifest greater incidence of negative psychological and physical outcomes, and lower levels of belongingness than the broader student population (Gaylord-Harden \& Cunningham, 2009; Meyer, 2003; Prada et al., 2021; Ramirez \& Paz Galupo, 2019; Wilson \& Liss, 2020). A local study analyzing the needs of French-speaking LGBTQ Manitoban adults found that many of these felt unwelcomed in both the local French-speaking community, and the broader LGBTQ community (Prada et al., 2021). It would be vital that in OLMC post-secondary settings, French-speaking LGBTQ individuals would be able to fully express themselves as such, without feeling the need to stifle one identity for another (Prada et al., 2021; Vu et al., 2011), as a positive affect toward the LGBTQ community, a sense of self-efficacy, and a sense of collective autonomy has been shown to favour psychosocial well-being (Kachanoff et al., 2020).

\section{Study Strengths and Limitations}

This study is among the first to gather valuable findings pertaining to sense of belonging and positive social climate of Canadian-born francophone students, anglophones choosing to study in a second language, and francophone international students on a post-secondary campus in an OLMC. One limitation is that we were unable to inquire among Métis students, a vulnerable segment of the francophone population (Gagnon, 2010). Interestingly, a recently published article describes Faculty of Education Métis students' thoughts on their cultural identity, reconciliation, and education in our post-secondary institution (Sims et al., 2021). Although not addressing 
belongingness directly, these students recognized their responsibility in taking leadership roles, such as within the student association, in promoting not only the minority language, but also other contemporary issues such as reconciliation and the environment. Common causes such as these could bring students together, decreasing segregation between cultural groups and increasing friendships across ethnolinguistic boundaries (Von Bergen et al., 2020). A second limitation is that participants identifying as anglophones were few in number, as were male francophones; this, however, was expected, as females generally outnumber male students in Canadian higher education (Turcotte, 2011). Lack of anglophone students' perspective may have influenced study results, as francophone students would have been better represented and provided a wider array of viewpoints.

\section{Conclusion}

Findings of this study show the dichotomy between domestic and international francophone students' sense of belonging and perceptions of campus climate on a OML campus, often associated to language insecurity in one of the official languages of Canada. In such a context, efforts should be undertaken to overcome language barriers between official language minority speakers, as these directly impact campus social climate and student sense of belonging, which may in turn influence their well-being and academic achievement. Training and support should be provided to staff and faculty for the promotion of positive interactions on campus; universities hosting students of multiple linguistic diversities should provide courses and campus events to stimulate intercultural knowledge and dialogue. With many post-secondary institutions returning to in-person activities following the COVID-19 pandemic, future studies examining the impact of online learning on the sense of belonging of students in post-secondary institutions should be pursued.

\section{References}

Allodi, M. W. (2010). The meaning of social climate of learning environments: Some reasons why we do not care enough about it. Learning Environments Research, 13(2), 89-104. https://doi.org/10.1007/ s10984-010-9072-9
Archibald, M. M. (2016). Investigator triangulation: A collaborative strategy with potential for mixed methods research. Journal of Mixed Methods Research, 10(3), 228-250. https://doi. org/10.1177/1558689815570092

Arnett, J. J. (2000). Emerging adulthood. A theory of development from the late teens through the twenties. The American Psychologist, 55(5), 469-480.

Backhaus, I., Lipson, S. K., Fisher, L. B., Kawachi, I., \& Pedrelli, P. (2021). Sexual assault, sense of belonging, depression and suicidality among LGBQ and heterosexual college students. Journal of American College Health: J of ACH, 69(4), 404-412. https:Il doi.org/10.1080/07448481.2019.1679155

Bahi, B., \& Mulatris, P. (2018). Hiérarchisations linguistiques et émergence de fragilités psychosociales: Un aperçu chez les jeunes en milieu franco-albertain. Linguistic Minorities and Society, 9, 168-184. https://doi.org/10.7202/1043501ar

Bennett, J. B. (2010). Social Climate Research. The Corsini Encyclopedia of Psychology. https://doi. org/10.1002/9780470479216.corpsy0885

Benoit, M., Bell, J., \& Lavoie, A. M. (2018). La santé mentale de jeunes étudiantes franco-ontariennes d'une université bilingue en Ontario: Les effets de la double minorisation et du bilinguisme instrumental sur les études et l'entrée en carrière. Linguistic Minorities and Society, 9, 207-226. https://doi. org/10.7202/1043503ar

Berry, J. W. (2005). Acculturation: Living successfully in two cultures. International Journal of Intercultural Relations, 29(6), 697-712. https://doi.org/10.1016/j. ijintrel.2005.07.013

Bouchard, L., Colman, I., \& Batista, R. (2018). Santé mentale chez les francophones en situation linguistique minoritaire. Reflets : revue d'intervention sociale et communautaire, 24(2), 74-96. https://doi. org/10.7202/1053864ar

Canadian Heritage. (n.d.). Official-Language Minority Communities Dashboard. https://experience. arcgis.com/experience/ede47be0589b4f678fecd11e2eff5852/page/page 2/ 
Chartier, M. J., Finlayson, G., Prior, H., McGowan, K.-L., Chen, H., Walld, R., \& de Rocquigny, J. (2014). Are there mental health differences between Francophone and non-Francophone populations in Manitoba? The Canadian Journal of Psychiatry, 59(7), 366-375. https://doi. org/10.1177/070674371405900704

Chen, J., \& Zhou, G. (2019). Chinese international students' sense of belonging in North American postsecondary institutions: A critical literature review. Brock Education Journal, 28(2), 48-63. https://doi. org/10.26522/brocked.v28i2.642

Clough, B. A., Nazareth, S. M., Day, J. J., \& Casey, L. M. (2018). A comparison of mental health literacy, attitudes, and help-seeking intentions among domestic and international tertiary students. British Journal of Guidance \& Counselling, 47(1), 123-135. https:// doi.org/10.1080/03069885.2018.1459473

Cormier, G. (2020). Perspectives et définitions scolaires de l'identité linguistique en milieu minoritaire: Comment les établissements scolaires de langue française répondent-ils aux besoins des élèves du 21e siècle face aux nombreuses transformations sociales, culturelles et démographiques en cours? La Francophonie : Un Objet à Redéfinir, 48(1), 53-72. https://doi.org/10.7202/1070100ar

de Moissac, D., Graham, J. M., Prada, K., Gueye, N. R., \& Rocque, R. (2020). Mental health status and help-seeking strategies of international students in Canada. Canadian Journal of Higher Education, 50(4), 52-71. https://doi.org/10.47678/cjhe. vi0.188815

de Moissac, D., Gueye, N. R., \& Rocque, R. (2019). My Health, Your Health...Our Health! A Study on Mental Health and Risk-Taking Behaviors of Young Adults On Five University Campuses in the Heart of Canada. (p. 194) [Research Report]. https://ustboniface. ca/ddemoissac/file/Mental-Health-English-v1.1.pdf

DeCou, C. R., Skewes, M. C., \& López, E. D. S. (2013). Traditional living and cultural ways as protective factors against suicide: Perceptions of Alaska Native university students. International Journal of Circumpolar Health, 72(1), 20968-5. https://doi. org/10.3402/ijch.v72i0.20968
Deschênes, É. (2018, September 26). Développer la compétence culturelle chez les enseignants: Mission impossible? Le Réseau EdCan. https://www. edcan.ca/articles/developper-la-competence-culturelle-chez-les-enseignants/?lang=fr

Drolet, M., Arcand, I., Benoît, J., Savard, J., Savard, S., \& Lagacé, J. (2015). Agir pour avoir accès à des services sociaux et de santé en français: Des Francophones en situation minoritaire nous enseignent quoi faire! Canadian Social Work Review, 32(1-2), 5-26. https://doi.org/10.7202/1034141ar

Falconer, J., \& Quesnel-Vallée, A. (2014). Les disparités d'accès aux soins de santé parmi la minorité de langue officielle au Québec. Recherches sociographiques, 55(3), 511-529. https://doi. org/10.7202/1028377ar

Franco, M. A., \& Kim, Y. K. (2018). Effects of campus climates for diversity on college GPA among Latinx students at selective universities: An examination by gender, first-generation college status, and immigrant status. In K. M. Soria (Ed.), Evaluating campus climate at US research universities: Opportunities for diversity and inclusion (pp. 25-48). Springer International. https://doi.org/10.1007/978-3-319-94836-2 2

Gagnon, D. (2010). Le contexte social et historique des revendications identitaires des jeunes Métis francophones du Manitoba. In L'identité des jeunes en contexte minoritaire (pp. 99-118). Les Presses de l'Université Laval.

Gaylord-Harden, N. K., \& Cunningham, J. A. (2009). The impact of racial discrimination and coping strategies on internalizing symptoms in African American youth. Journal of Youth and Adolescence, 38(4), 532-543. https://doi.org/10.1007/s10964-008-9377-5

Givergis, K. (2019, December 4). The Benefits of Learning French in Canada. World Education Services. https://www.wes.org/advisor-blog/benefits-learning-french-canadal

Gopalan, M., \& Brady, S. T. (2019). College Students' Sense of Belonging: A National Perspective. Educational Researcher, 49(2), 134-137. https://doi. org/10.3102/0013189X19897622 
Gueye, N. R., de Moissac, D., \& Touchette, A. (2018). Profils ethnolinguistique et de santé mentale de jeunes étudiantes et étudiants d'un établissement d'enseignement postsecondaire francophone en contexte minoritaire dans l'Ouest canadien. Canadian Journal of Community Mental Health, 37(1), 13-28. https://doi.org/10.7870/cjcmh-2018-004

Gummadam, P., Pittman, L. D., \& loffe, M. (2016). School belonging, ethnic identity, and psychological adjustment among ethnic minority college students. The Journal of Experimental Education, 84(2), 289-306. https://doi.org/10.1080/00220973.2015.1048844

Hausmann, L. R. M., Schofield, J. W., \& Woods, R. L. (2007). Sense of Belonging as a Predictor of Intentions to Persist Among African American and White First-Year College Students. Research in Higher Education, 48(7), 803-839. https://doi.org/10.1007/ s11162-007-9052-9

Huang, S. L., \& Mussap, A. J. (2018). Maladaptive perfectionism, acculturative stress and depression in Asian international university students. Journal of Psychologists and Counsellors in Schools, 28(2), 185-196. https://doi.org/10.1017/jgc.2016.18

Hunt, C., Gibson, G. C., Vander Horst, A., Cleveland, K. A., Wawrosch, C., Granot, M., Kuhn, T., Woolverton, C. J., \& Hughes, J. W. (2021). Gender diverse college students exhibit higher psychological distress than male and female peers during the novel coronavirus (COVID-19) pandemic. Psychology of Sexual Orientation and Gender Diversity, 8(2), 238-244. https://doi.org/10.1037/sgd0000461

Hurtado, S., Alvarado, A. R., \& Guillermo-Wann, C. (2015). Creating Inclusive Environments: The Mediating Effect of Faculty and Staff Validation on the Relationship of Discrimination/Bias to Students' Sense of Belonging. JCSCORE, 1(1), 59-81. https://doi.org/10.15763/issn.26422387.2015.1.1.59-81

Kachanoff, F. J., Cooligan, F., Caouette, J., \& Wohl, M. J. A. (2020). Free to fly the rainbow flag: The relation between collective autonomy and psychological well-being amongst LGBTQ+ individuals. Self and Identity, 20(6), 741-773. https://doi.org/10. $\underline{1080 / 15298868.2020 .1768890}$
Labrèche, Y., \& Piquemal, N. (2011). Parcours identitaires des minorités involontaires au Manitoba français: Vers une éthique en matière de dialogue, de réciprocité et d'éducation interculturelle. Francophonies d'Amérique, 32, 187-207. https://doi. org/10.7202/1014050ar

Lafrance, M. (2008). The process of minoritisation of the Franco-Ontarian identity and its numerous articulations: A Montfort Hospital case study [Thesis]. Université de Montréal.

Levesque, A. (2015). Identité, culture et représentations de la santé et des maladies. Cahiers Franco-Canadiens de l'Ouest, 27(1), 35-56. https://doi. org/10.7202/1031241ar

Levesque, A., \& de Moissac, D. (2018). Identité ethnolinguistique, continuité cultuelle et santé mentale chez les jeunes Franco-Manitobains: Une analyse exploratoire. Minorités linguistiques et société, 9, 185-206. https://doi.org/10.7202/1043502ar

Martinez, E. F., \& Munsch, P. (2019). Developing a Sense of Belonging in Community College Students. About Campus: Enriching the Student Learning Experience, 24(5), 30-34. https://doi. org/10.1177/1086482219896044

McGuirk, E., \& Frazer, P. (2021). The impact of the campus climate and mental health literacy on students' wellbeing. The Journal of Mental Health Training, Education and Practice (ahead-of-print). https://doi. org/10.1108/JMHTEP-12-2020-0088

Meeuwisse, M., Severiens, S. E., \& Born, M. Ph. (2010). Learning Environment, Interaction, Sense of Belonging and Study Success in Ethnically Diverse Student Groups. Research in Higher Education, 51(6), 528-545. https://doi.org/10.1007/s11162-010-9168-1

Mehta, R., \& Aguilera, E. (2020). A critical approach to humanizing pedagogies in online teaching and learning. The International Journal of Information and Learning Technology, 37(3), 109-120. https:// doi.org/10.1108/IJILT-10-2019-0099

Mesidor, J. K., \& Sly, K. F. (2016). Factors that contribute to the adjustment of international students. Journal of International Students, 6(1), 262-282. https://doi.org/10.32674/jis.v6i1.569 
Meyer, I. H. (2003). Prejudice, social stress, and mental health in lesbian, gay, and bisexual populations: Conceptual issues and research evidence. Psychological Bulletin, 129(5), 674-697. https://doi. org/10.1037/0033-2909.129.5.674

Mougeon, F., \& Rehner, K. (2015). Engagement portraits and (socio)linguistic performance: $A$ transversal and longitudinal study of advanced L2 learners. Studies in Second Language Acquisition, 37(3), 425-456. https://doi.org/10.1017/ S0272263114000369

Noël, J., \& Beaton, A. M. (2010). Perceptions de groupes, profils identitaires collectifs et bien-être psychologique: La perspective des jeunes Acadiens du sud-est du Nouveau-Brunswick. Revue de I'Université de Moncton, 41(1), 211-246. https://doi. org/10.7202/1006095ar

Pilote, A., \& Joncas, J.-A. (2016). La construction identitaire linguistique et culturelle durant un programme universitaire d'éducation en français en milieu minoritaire: Le cas de cinq étudiants fransaskois. Minorités linguistiques et société / Linguistic Minorities and Society, 7, 142-169. https://doi. org/10.7202/1036420ar

Prada, K., de Moissac, D., \& Gueye, N. R. (2021). Des nôtres: Une analyse des besoins des personnes LGBTQ2S d'expression française du Manitoba ( $p$. p.103). Université de Saint-Boniface.

Pratt, R., Burman, E., \& Chantler, K. (2004). Towards understanding domestic violence: Reflections on research and the 'domestic violence and minoritization' project. Journal of Community \& Applied Social Psychology, 14(1), 33-43. https://doi.org/10.1002/casp.758

Puchala, C., Leis, A. F., Lim, H., \& Tempier, R. (2013). Official language minority communities in Canada: Is linguistic minority status a determinant of mental health? Canadian Journal of Public Health, 104(6), S5-S11. https://doi.org/10.17269/cjph.104.3480

Ramirez, J. L., \& Paz Galupo, M. (2019). Multiple minority stress: The role of proximal and distal stress on mental health outcomes among lesbian, gay, and bisexual people of color. Journal of Gay \& Lesbian Mental Health, 23(2), 145-167. https://doi. org/10.1080/19359705.2019.1568946
Robert, S. (2018). Construction identitaire en milieu minoritaire: Perceptions des étudiants en Faculté d'éducation quant à leur cheminement et au rôle qu'ils sont appelés à jouer auprès des élèves dans les écoles francophones au Manitoba [Masters thesis, Université de Saint-Boniface]. https://mspace. lib.umanitoba.ca/xmlui/handle/1993/33428

Rocque, R., de Moissac, D., Ndeye, R., Delaquis, S., Vigier, D., \& Perron, C. (2019, June 13). Mental Health and Well-Being of University Students in a Francophone Minority Setting, A Survey Study Comparing Findings from 2012 to 2018 [Oral presentation]. Society for Teaching and Learning in Higher Education Annual Conference, Winnipeg, MB, Canada.

Shadowen, N. L., Williamson, A. A., Guerra, N. G., Ammigan, R., \& Drexler, M. L. (2019). Prevalence and correlates of depressive symptoms among international students: Implications for university support offices. Journal of International Students, 9(1), 129-149. https://doi.org/10.32674/jis.v9i1.277

Sims, L., Gagné, R., Carrière, A., Vandal, A., Fowler, A., Brémault, C., \& Grégoire, S. (2021). T'es métis, toi?! Des réflexions d'étudiantes et d'étudiants universitaires franco-manitobains métis à propos de leur identité culturelle, de la réconciliation et de l'éducation. Éducation et francophonie, 49(1), 133-152. https://doi.org/10.7202/1077005ar

Smith, C., Whiteside, B., Blanchard, S., \& Martin, C. (2013). International student support services at Ontario universities. Strategic Enrollment Management Quarterly, 1(1), 55-66. https://doi. org/10.1002/sem3.20005

Sousa, A. (2021). Dialogue in Online Learning Spaces: How Transitioning to Online Learning during a Pandemic Impacts Critical Classroom Dialogue and Inclusivity. Journal of Teaching and Learning with Technology, 10(1), Article 1. https://doi. org/10.14434/jottt.v10i1.31383

Stein, B. D., Sontag-Padilla, L., Ashwood, J. S., Woodbridge, M. W., Eberhart, N. K., May, L., Seelam, R., Briscombe, B., Mendelsohn, J., \& D’Amico, E. J. (2016, April 24). Campus Climate Matters: Changing the Mental Health Climate on College Cam- 
puses Improves Student Outcomes and Benefits Society. RAND Corporation. https://www.rand.org/ pubs/research briefs/RB9904.html

Tajfel, H. (1978). Differentiation between social groups: Studies in the social psychology of intergroup relations (pp. xv, 474). Academic Press.

Taylor, D. M. (1997). The quest for collective identity: The plight of disadvantaged ethnic minorities. Canadian Psychology/Psychologie Canadienne, 38(3), 174-190. https://doi.org/10.1037/0708-5591.38.3.174

Thomson, C., \& Esses, V. M. (2016). Helping the Transition: Mentorship to Support International Students in Canada. Journal of International Students, 6(4), 873-886. https://doi.org/10.32674/jis.v6i4.323

Thomson, M. D., \& Hoffman-Goetz, L. (2009). Defining and measuring acculturation: A systematic review of public health studies with Hispanic populations in the United States. Social Science \& Medicine (1982), 69(7), 983-991. https://doi.org/10.1016/j. socscimed.2009.05.011

Turcotte, M. (2011). Women and Education: A Gender-based Statistical Report (Component of Statistics Canada Catalogue no. 89-503-X). https:/l www150.statcan.gc.ca/n1/pub/89-503-x/2010001/ article/11542-eng.pdf

Von Bergen, C. W., Bressler, M. S., \& Whitlock, D. W. (2020). Separate but Equal on College Campuses: A Case of "Déjà Vu' All over Again." Research in Higher Education Journal, 38. https://eric.ed.gov ? ?id=EJ1263825

Vu, L., Choi, K., \& Do, T. (2011). Correlates of sexual, ethnic, and dual identity: A study of young Asian and Pacific Islander men who have sex with men. AIDS Education and Prevention: Official Publication of the International Society for AIDS Education, 23(5), 423-436. https://doi.org/10.1521/ aeap.2011.23.5.423

Wells, A. V., \& Horn, C. (2015). The Asian American College Experience at a Diverse Institution: Campus Climate as a Predictor of Sense of Belonging. Journal of Student Affairs Research and Practice, 52(2), 149-163. https://doi.org/10.1080/19496591.2 $\underline{015.1041867}$
Wilson, L. C., \& Liss, M. (2020). Safety and belonging as explanations for mental health disparities among sexual minority college students. Psychology of Sexual Orientation and Gender Diversity. https:ll doi.org/10.1037/sgd000041

Yang, J., \& Rechner, K. (2015). Learner beliefs about sociolinguistic competence: A qualitative case study of four university second language learners. Language Learning in Higher Education, 5(1), 157-180. https://doi.org/10.1515/cercles-2015-0008

\section{Contact Information}

Danielle de Moissac

ddemoissac@ustboniface.ca 